\title{
Impact of energy economy development on the region's population life quality
}

\author{
Natalia Zlobina ${ }^{1}$, Oleg Kondrakov ${ }^{2}$, Elena Merkulova ${ }^{1}$, Olga Muratova $^{1}$, and Yulia \\ Vetakova $^{3, *}$ \\ ${ }^{1}$ Tambov State Technical University, 392000, 106, Sovetskaya Str., Tambov, Russia \\ ${ }^{2}$ Derzhavin Tambov State University, 392000, 33 Internatsionalnaya Str., Tambov, Russia \\ ${ }^{3}$ Southwest State University, 305004, 94, 50 Let Oktyabrya Str., Kursk, Russia
}

\begin{abstract}
Regional economic development depends on development of fuel and energy industry facilities capable of ensuring a stable and reliable supply of energy carriers. At present, it is impossible to imagine livelihood of population without electrical energy. Russia produces 1094 billion $\mathrm{kWh}$ of electrical energy, of which 580 billion $\mathrm{kWh}$ is consumed by industry. Electrical energy is the basis for development of all types of economic activities. It is a condition for creation of material values and an increase in the standard of living of population. Modern industrial technologies are characterized by high energy intensity. Industry is dependent on electrical energy which drives power equipment. Electric power affects productivity which is the main indicator of production efficiency. The increase in GRP is mainly accounted for manufacturing industry (high-tech production) and service sector. Such indicators as GRP per capita, the volume of goods shipped by manufacturing industries, consumption of electricity by industry, and electric power per worker characterize sustainable socioeconomic development of regions. It is relevant to conduct a statistical analysis of these indicators and identify development prospects to ensure energy security of regions.
\end{abstract}

\section{Introduction}

One of the stably consumed products by humanity is energy. The level of development of electric power industry determines scientific and technical progress. Any technological processes are a priori energy consumers. Electrical energy is necessary when transporting raw materials and finished products, crushing, drying, mixing, grinding, centrifuging, separating, filtering, conducting electrochemical reactions, etc. Electrical energy is used in electrostatic phenomena (deposition of dust and fog, electro-cracking). Thus, electrical energy is necessary in all physical and mechanical processes for the processing of raw materials.

Industrial output averages $25 \%$ of Russia's GDP. The level of regional economic development is determined by the GRP per capita, which in turn depends on the volume of goods shipped. An important indicator of labour efficiency is electric power per worker,

\footnotetext{
*Corresponding author: vertakova7@ya.ru
} 
which depends on the amount of electricity consumed. Russia has a huge resource potential, which is a nationwide asset. The main problem is how to use it correctly. This requires an analysis of economic and energy development of the regions and identification of their potential.

Regional economic policy should be based on the possibilities of providing industry with energy resources, in particular, with electrical energy. Patterns of development of the economies of Russian regions are revealed while researching the following indicators: GRP per capita, the volume of goods shipped by manufacturing, electricity consumption by industry and electric power per worker. The aim of the research is to study these indicators of regions and to determine their vector of economic and energy development.

Methodological approaches to the study of the energy complex in the system of national economy are investigated in the works of L. Matraeva [1] and T. Miroshnikova [2]. These authors investigated the patterns of electricity consumption in Russia at the regional level.

The study of economic systems and their structural elements, in particular, the energy component is described in the works of V. Lezier, [3], T. Meshcheryakova [4].

Among the authors studying economic security in the energy sector we single out V.V. Klimenko [5], M.F. Keating [6], A. Mottaeva [7], I. Bashmakov[8]. They note the role of energy in the national security system, consider threats to energy security, and identify problems and development prospects of the fuel and energy industry facilities. The nature of territorial relations in the regional economy and the priorities of socio-economic development of the Ural region are considered in the works of A. I. Tatarkin [9]. A significant contribution to the forecasting of the development and location of the fuel and energy sector was made by A.M. Mastepanov [10], A. Gorshkov [11], Y. Vertakova [12], I. Kuzminov [13].

\section{Materials and Methods}

The research tools include methods of analyzing static and dynamic information. The task is to analyze the level of regional economic development and indicators affecting the quality of life for the population: GRP per capita, the volume of goods shipped by manufacturing industries, electricity consumption by industry and electric power per worker. The authors assume that the quality of life for the population depends on the level of development of industrial production and energy.

A statistical approach to the study of indicators characterizing development of industry in the regions of Russia was implemented as a methodological base of the research. When conducting this study, the following methods were used: economic and statistical analysis (comparison, calculation of absolute, relative and mean values, tabular, graphical display of information), expert estimates and forecasting, multidimensional studies (principal component method, cluster analysis based on the Ward method, integration on basis of geometric mean). The study used Microsoft Excel and IBM SPSS Statistica application software, which increased the accuracy of calculations. The study made it possible to summarize the characteristics of the regions from the standpoint of the security of industrial electricity and to determine the vectors of regional development.

\section{Results}

GRP per capita characterizes the level of socio-economic development. Analysis of the indicator allows us to conclude that there is a significant right-sided distribution asymmetry $(5,259)$, which indicates that in most regions there is an excess of the average Russian results for this indicator (Table 1). A significant positive kurtosis of 31,747 indicates a 
peaked character of the distribution, which means the concentration of regions in the area of average Russian consumption, as well as the presence of anomalous values. There is a discrepancy between the quartile distance and the standard deviation.

Table 1. Calculations of descriptive statistics of GRP per capita

\begin{tabular}{|l|l|l|l|l|}
\hline & GRP per capita & $\begin{array}{l}\text { Electricity } \\
\text { consumption } \\
\text { industry }\end{array}$ & $\begin{array}{l}\text { Volume of } \\
\text { bhipped } \\
\text { manufacturing }\end{array}$ & $\begin{array}{r}\text { goods } \\
\text { by }\end{array}$ \\
per worker
\end{tabular}

The lowest GRP per capita is observed in the regions of the Republic of Ingushetia 106956 rubles, the Chechen Republic - 111705 rubles, the city of Sevastopol - 119385 rubles, the Republic of Crimea - 139873 rubles, the Kabardino-Balkarian Republic 139909 rubles, which is connected with a weak development of manufacturing and, as a consequence, a low standard of living of the population in the listed regions.

The average GRP per capita in the regions of the Russian Federation was 473844.62 rubles. The value of the median indicator of 317763.60 rubles is below the average, therefore there is a right-sided asymmetry, indicating a positive trend of upward bias for the most regions of the Russian Federation. The maximum value of the indicator in the Yamalo-Nenets Autonomous Area is 3336453 rubles, the Nenets Autonomous Area 5210144 rubles, the Khanty-Mansiysk Autonomous Area - 1947653 rubles, Moscow 1102496.4 rubles, the Sakhalin and Tyumen regions - 1716734 and 1626160 rubles respectively. In these regions the bulk of the oil and gas industry is concentrated. They are the donor regions and lead in a number of economic indicators. In these regions an increased share of GRP is accounted for the enterprises of the metallurgical, fuel and energy industries.

Consumption of primary energy resources, electricity, in particular is an indicator of economic development. The average level of consumption of electrical energy in regional industry of the Russian Federation is 6579.1341 million $\mathrm{kWh}$. The excess of electrical 
energy consumption more than 3 times is typical for Khanty-Mansiysk Autonomous Area 64646.40 million kWh, Krasnoyarsk Territory - 39114.10 million kWh, Irkutsk Region 35780.70 million kWh, Kemerovo Region - 25629.00 million kWh, the Sverdlovsk Region - 25623.40 million $\mathrm{kWh}$, which indicates a developed industry level. Manufacturing is developing in these regions along with oil and gas industry. The regions with the lowest electricity consumption include the Republic of Kalmykia - 41 million kWh, Republic of Ingushetia - 80 million $\mathrm{kWh}$, the Republic of Altai - 93.10 million $\mathrm{kWh}$, the Republic of Tyva -145.70 million $\mathrm{kWh}$, the city of Sevastopol -163.80 million $\mathrm{kWh}$. In these regions industry is poorly developed.

The value of the sample median of electrical energy consumption of 3368.80 is two times lower than the average value, therefore, there is a significant right-hand asymmetry (Table 1). The value of kurtosis (31.747) indicates a very significant peaked character of the distribution with abnormal outlying cases.

The volume of goods shipped by manufacturing industries among the regions of the Russian Federation is led by Moscow - 5156077 million rubles, St. Petersburg - 2263057 million rubles, Moscow Region - 2086349 million rubles, Sverdlovsk region - 1659144 million rubles, The Republic of Tatarstan - 1369000 million rubles. In these regions manufacturing is concentrated, representing the automotive industry, machine-tool construction, high-tech engineering industries, the production of building materials, and various sectors of the light and food industries.

The data in Table 1 shows that the median value is lower than the average. Therefore, there is a right-sided asymmetry indicating a shift in most regions of the Russian Federation towards a lower level of the volume of goods shipped by manufacturing industries relative to the average Russian level. The value of kurtosis (2.7) indicates the peaked character of the distribution, which means the concentration of regions in the area of average Russian consumption and the presence of anomalous values.

Oil processing and petrochemical complexes occupy a large share in the processing industry of Tatarstan. One of the leading branches of mechanical engineering are automobile and aircraft building. Petrochemical plants produce more than $11 \%$ of the total chemical production in Russia. The Republic of Tatarstan produce $64 \%$ of polystyrene, $40 \%$ of synthetic rubber and $14 \%$ of synthetic detergents. Tatarstan is the only producer in Russia of polycarbonate, halobutyl rubber and sevilen.

A large industrial centre of the Urals is the Sverdlovsk region. The main economic activities in the Sverdlovsk region are ferrous and non-ferrous metallurgy and mining. Mechanical engineering is well developed in the region. In the Sverdlovsk region $31 \%$ of ferrous metallurgy and 19\% of non-ferrous metallurgy are concentrated. Enrichment of colored ore and uranium is well developed in the region as well. The largest enterprises of heavy mechanical engineering are Uralmash Machine-Building Corporation (Yekaterinburg), which produces mining and metallurgical equipment; Open Joint Stock Company "Research and Production Corporation "Uralvagonzavod" (Nizhny Tagil), producing heavy-duty cars; Open Joint Stock Company “Turbomotorny zavod”, producing turbines.

In the Moscow Region industry uses imported raw materials. The machine-building industry is widely represented here: machinery and equipment for the power industry, ferrous metallurgy, construction, light industry, transport and agriculture. Ferrous metallurgy in the Moscow Region is represented by the metallurgical plant OJSC Electrostal, which supplies metal products to domestic and foreign markets. The food industry in the Moscow Region is $27 \%$ of the GRP. The Moscow Region occupies a leading place in the production of diesel locomotives and wagons.

The efficiency criterion is the degree of effectiveness of energy costs on products manufacturing. Electric power per worker is consumption of electrical energy per unit of 
production. The Republic of Khakassia has $1364404.5 \mathrm{kWh}$, the Irkutsk region - 428632 kWh, the Krasnoyarsk Territory - 264924 kWh, the Murmansk Region - 194965 kWh, the Republic of Karelia - $168914 \mathrm{kWh}$.

The Chukotka Autonomous Area, the city of Sevastopol, the Republic of Tyva, the Republic of Kalmykia and the Republic of Ingushetia have low indicators of electric power per capita (correspondingly $0 ; 1563 ; 1644 ; 3454$ ). These regions also have low indicators of electric power consumed in industrial production.

The analysis shows that regions with a high rate of electric power per worker have cheap electrical energy generated at hydro and nuclear power plants (Table 1). For example, in the Republic of Khakassia there are two large hydroelectric power stations. The value of the excess of electric power per capita (60.433) indicates the presence of a strong anomalous ejection. Significant right-sided asymmetry determines the average value, which is 2.4 times higher than the median and the value of its index equal to 7.368. Using percentiles, we determine that the values are below average in Russia: $80 \%$ of regions in terms of GRP per capita, $60 \%$ of regions in terms of the volume of goods shipped, $80 \%$ in terms of electricity consumption by industry, $80 \%$ in terms of electric power per worker. The percentile data shows that only $25 \%$ of regions have high socio-economic development.

Research show uneven socio-economic development of regions. Industrial output of 74 $\%$ is produced in the European part of Russia, but there is a shortage of fuel resources. In the Eastern part of Russia $92 \%$ of gas, $69 \%$ of oil, $79 \%$ of coal and $62 \%$ of non-ferrous metallurgy are produced.

In St. Petersburg production of high-tech complex and precise engineering is concentrated. The research capacity of products manufactured in St. Petersburg is 3 times higher than the average for Russia. Moscow and St. Petersburg determine scientific and technical progress in Russia.

The main industry in the economy of the Far East is the food industry (fish industry). The Far Eastern economic region is rich in gold, diamonds, iron ore and oil and gas deposits. The major constraint for development of manufacturing in the Far East is the lack of its own fuel and energy resources.

There is a large hydropower potential in the West Siberian economic region. The lowest costs for electrical energy generation are observed in the Yenisei basin. Large hydropower plants such as Sayano-Shushenskaya, Krasnoyarsk, Bratsk, Ust-Ilim are located there. Cost value of non-ferrous metallurgy products in the East-Siberian economic region is two times cheaper than in the European zone. The Ural economic region has all kinds of mineral ores of ferrous and non-ferrous metals, potash salts and semi-precious stones.

Currently, a promising direction for the economy of Siberia and the Far East are improvement of the economic structure, development of infrastructure and manufacturing in the Eastern part of Russia; promoting investment in modernization and technological reequipment of manufacturing. Unfortunately, there is currently a shortage of labour, material and financial resources.

The Central Economic Region (17.8\% of total Russian production), Eastern Siberia $(14.7 \%)$, the Urals $(15.3 \%)$ and Western Siberia (14.3\%) stand out in terms of energy generation. Moscow and the Moscow Region, the Khanty-Mansiysk Autonomous Area, the Irkutsk Region, the Krasnoyarsk Territory, and the Sverdlovsk Region are the leaders among the entities of the Russian Federation.

The largest thermal power plants with a capacity of more than 2 million $\mathrm{kW}$ each are Surgut 1 and Surgut 2 (Khanty-Mansiysk Autonomous Area), Konakovskaya (Tver Region), Kirishskaya (Leningrad Region) and Perm. Thermal power plants with an installed capacity of 1.2-2 million kW: Kashirskaya and Shaturskaya (Moscow Region), Zainskoye (Republic of Tatarstan), Krasnoyarskaya 2 and Berezovskaya (Krasnoyarsk 
Territory), Stavropol, Karmanovskaya (Republic of Bashkortostan), Troitskaya (Chelyabinsk Region).

Large nuclear power plants are Kalinin - 1485 MW (Tver Region), Leningrad - 4200 MW (Leningrad Region), Kursk - 4000 MW (Kursk Region), Balakovo - 4000 MW (Saratov Region), Rostov - 4000 MW (Rostov Region), Smolensk - 3000 MW (Smolensk Region), Novovoronezh - 2597 MW (Voronezh Region).

Large hydropower plants are Sayano-Shushenskaya - 6400 MW (Republic of Khakassia), Krasnoyarskaya -6000 MW, Bratskaya - 4500 MW (Irkutsk Region), UstIlimsk - 3840 MW (Irkutsk Region), Volzhskaya -2592 MW (Volgograd Region), Zhiguli Region - 2330.5 MW (Samara Region), Bureiskaya - 2010 MW (Amur Region), Cheboksary - 1370 MW (Republic of Chuvashia). Economically developed regions have a large production potential. In those regions where industrial production is developed, a large amount of GRP is observed.

\section{Discussion}

The Institute of Energy Research has developed a project called "Developing Methodological Foundations and Means for Optimizing Interconnections in the Development and Location of the Economy and Energy", where rational zoning of the territory of the Russian Federation has been proposed according to the conditions for locating production and consumption of energy resources and existing and forecasted transport and energy relations. Within the project the features of the energy structure were revealed, the analysis of energy consumption and production of energy resources was carried out in relation to the area and population of the territory of Russia. The factors determining the density of energy consumption were revealed.

Analysis of the research shows that there are many approaches to the problem of energy and economic security. There are few works devoted to the analysis of the differentiation of regions in terms of economic development in the context of resource provision of industry. The insufficient theoretical and methodological basis of the orientations of the regional economy in conjunction with energy should be noted. There is no systematization of regions by levels of economic development and energy supply.

\section{Conclusions}

Currently each region should make the most efficient use of its natural, geographical, production, intellectual and technological advantages for the development of the economy. All regions are at different levels of economic development. Moscow has a unique investment and scientific potential. The main advantage of Moscow is its status as a financial centre. Moscow banks have more than $80 \%$ of the assets of the entire banking system of the Russian Federation. About 1000 securities circulate on the Moscow stock exchanges. The regions of Siberia have a rich resource potential.

Such regions as Tyumen, Tomsk, Krasnoyarsk Territory and the Republic of Sakha Yakutia are rich in natural resources. In the Krasnoyarsk Territory and the Tomsk Region there is a successful symbiosis of the wealth of natural resources and the scientific base. The Krasnodar Territory, the Republic of Crimea, the Murmansk Region, the Sakhalin Region, the Republic of Karelia and the Komi Republic are geographically adapted for the development of renewable energy.

Russia annually produces about 1000 billion kWh of electricity, and according to this indicator it takes the 4th place in the world, after the USA, China and Japan. The leaders in the production of electricity among the economic regions of Russia are the Central 
Economic Region, Eastern Siberia and the Urals. Nuclear power plants dominate in the central region (atomic energy), and hydroelectric power stations (hydropower) dominate in Siberia. Electrical energy produced at hydroelectric power plants has a low cost, ease of regulation of production and environmental friendliness. Large hydropower plants are located in the basin of the Angara-Yenisei cascade (Sayano-Shushenskaya, Krasnoyarsk, Irkutsk, Bratsk, Ust-Ilim). The powerful rivers of Siberia, the Yenisei and the Angara make it possible to generate electrical energy at a cost of 5 times cheaper than power stations in the European part of Russia while reducing the level of capital investments.

Eastern Siberia has the highest rates of electricity generation and the lowest do the North Caucasus and the Volga-Vyatka Region. The optimal location of the objects generating electrical energy in combination with the needs and location of industrial enterprises are determined by the methods of economic regulation.

All regions have adopted laws to support investment attractiveness. Investment attractiveness is supported by the following actions: development and adoption of an appropriate legislative framework; infrastructure development; business security; the establishment of tax incentives for investors in the form of full or partial exemption from taxes, deferment, installments, changes in the timing of their payment of a tax credit; leasing to investors on preferential terms of premises and other property; providing investors with preferential conditions for the use of natural resources, if it does not contradict the legislation of the Russian Federation; interest rate subsidies for commercial loans; business security; reduction of bureaucratic obstacles; provision of budget loans, credits and grants.

To ensure high growth rates of GRP and economic development a policy of increasing competitiveness is required, namely: diversifying the economy, using the competitive advantages of the regions (geographic, natural, technological, material, financial, etc.), technological re-equipment of industrial enterprises, creating conditions for new types of production, expansion of the production base. An important characteristic of the economic system is economic security, which determines the ability to support the livelihoods of the population and the sustainable provision of fuel and energy resources of the national economy, despite the impact of external and internal threats.

In order to ensure the energy security of the regions such promising areas as creating a unified monitoring system in the energy sector, rational use of energy resources (especially energy-deficient regions), ensuring the reliability of inter-regional energy infrastructure, introducing advanced technologies in the power industry (for example, Smart Grid), developing alternative energy, direction of investments in modernization, technical and technological re-equipment of the fuel and energy industry facilities should be developed. The obtained results can be used to shape the state economic policy taking into account regional features.

\section{References}

1. L. Matraeva, P. Solodukha, S. Erokhin, M. Babenko, Energy Policy, 125, 478-486 (2019) doi: 10.1016/j.enpol.2018.10.049

2. T. Miroshnikova, N. Taskaeva, Proceedings of the XV International Conference Topical Problems of Architecture, Civil Engineering, Energy Efficiency and Ecology, 73, (2016) doi: 10.1051/matecconf/20167307006

3. V. Lezier, M. Gusarova, A. Kopytova, Proceedings of the Conference on Energy Management of Municipal Transportation Facilities and Transport, 90, (2017) doi: $10.1088 / 1755-1315 / 90 / 1 / 012034$ 
4. T. Meshcheryakova, International Science Conference SPBWOSCE, Smart City, 106, (2016) doi: 10.1051/matecconf/201710606021

5. V. V. Klimenko, A. S. Ginzburg, P. F. Demchenko, A. G. Tereshin, I. N. Belova, E. V. Kasilova, Doklady Physics, 61(10), 521-525 (2019) doi: 10.1134/S1028335816100050

6. M. F. Keating, C. Kuzemko, A. V. Belyi, A. Goldthau, Dynamics of Energy Governance in Europe and Russia, 1-19 (2012)

7. A. Mottaeva, Proceedings of the Conference on Energy Management of Municipal Transportation Facilities and Transport (EMMFT 2017), 90, (2017) doi: 10.1088/17551315/90/1/012124

8. I. Bashmakov, Energy Efficiency, 2(4), 369-386 (2009) doi: 10.1007/s12053-0099050-1

9. A. I. Tatarkin, Ekonomika Regiona-Economy of Region, 12(1), 9-27 (2016) doi: 10.17059/2016-1-1

10. A. Mastepanov, O. Pluzhnikov, V. Berdin, V. Gavrilov, Climate Policy, 1(1), 9-27 (2001) doi: 10.3763/cpol.2001.0111

11. A. Gorshkov, V. Murgul, O. Oliynyk, Proceedings of the International Scientific Conference Week of Science in SPbPU - Civil Engineering (SPbWOSCE), 53 (2016) doi: 10.1051/matecconf $/ 20165301045$

12. Y. Vertakova, V. Plotnikov, ECONOMIC ANNALS-XXI, 166(7-8), 4-10 (2017) doi: 10.21003/ea.V166-01

13. I. Kuzminov, A. Bereznoy, P. Bakhtin, Foresight, 19(2), 174-197 (2017) doi: 10.1108/FS-06-2016-0026 